\title{
EARLY MEDIEVAL WINGED SPEARHEADS FROM PRESENT-DAY SERBIA
}

\author{
Aleksandar Sajdl \\ Petrovaradin \\ \begin{tabular}{r|l} 
e-mail: aleksandar.sajdl@gmail.com & Original scientific paper \\
Received: 27. 4. 2020. & UDC: : 904:623.444.4"653"(497.11) \\
Accepted: 23. 6. 2020. &
\end{tabular}
}

\begin{abstract}
In Bačevci, a village on the bank of the Drina, a winged spearhead with a preserved piece of a wooden shaft was found by accident. Only two similar spearheads have been discovered in Serbia, also without an archaeological context. The paper describes these spearheads and presents the results of botanical, radiographic, typological, and chronological analyses. The lack of context challenges archaeological interpretations.
\end{abstract}

Keywords: Syrmia, Drina, Bačevci, Vinča, Fruška Gora, winged spearhead, early Middle Ages

\section{Introduction}

Europe yielded a large number of early medieval winged spearheads. They were being discovered accidentally (as a rule of thumb) or during archaeological excavations (as an exception), from Scandinavia (e.g. Petersen 1919) and the British Isles (e.g. Shetelig 1940) in the north, across Western and Central Europe (e.g. Husár 2014; Westphal 2002; Ypey 1982), up to the Balkan Peninsula (e.g. Bitenc and Knific 2009; Demo 2011; Miletić 1991) and the Mediterranean Sea in the south (Schwarzer 2004), and the Mureș Valley in the east (Pinter 1998). Three of them have been discovered on the territory of present-day Serbia ${ }^{1}$ (Fig. 1 ), each without a proper archaeological context. The aim of this paper is to describe these weapons, compare them with other similar artefacts, classify, and date them. Without an archeological context, any deeper analysis seems elusive.

\section{The most recent discovery}

In May 2017 a member of a closed Facebook group posted three photos of a winged spearhead thrust into the ground, with preserved remains of a wooden shaft in its socket, stating that 'they' found it during a reconnaissance

\footnotetext{
${ }^{1}$ Whenever the name of a country is mentioned in this paper, it refers to that country with the borders at the time of writing (March/April 2020), unless specified otherwise. 


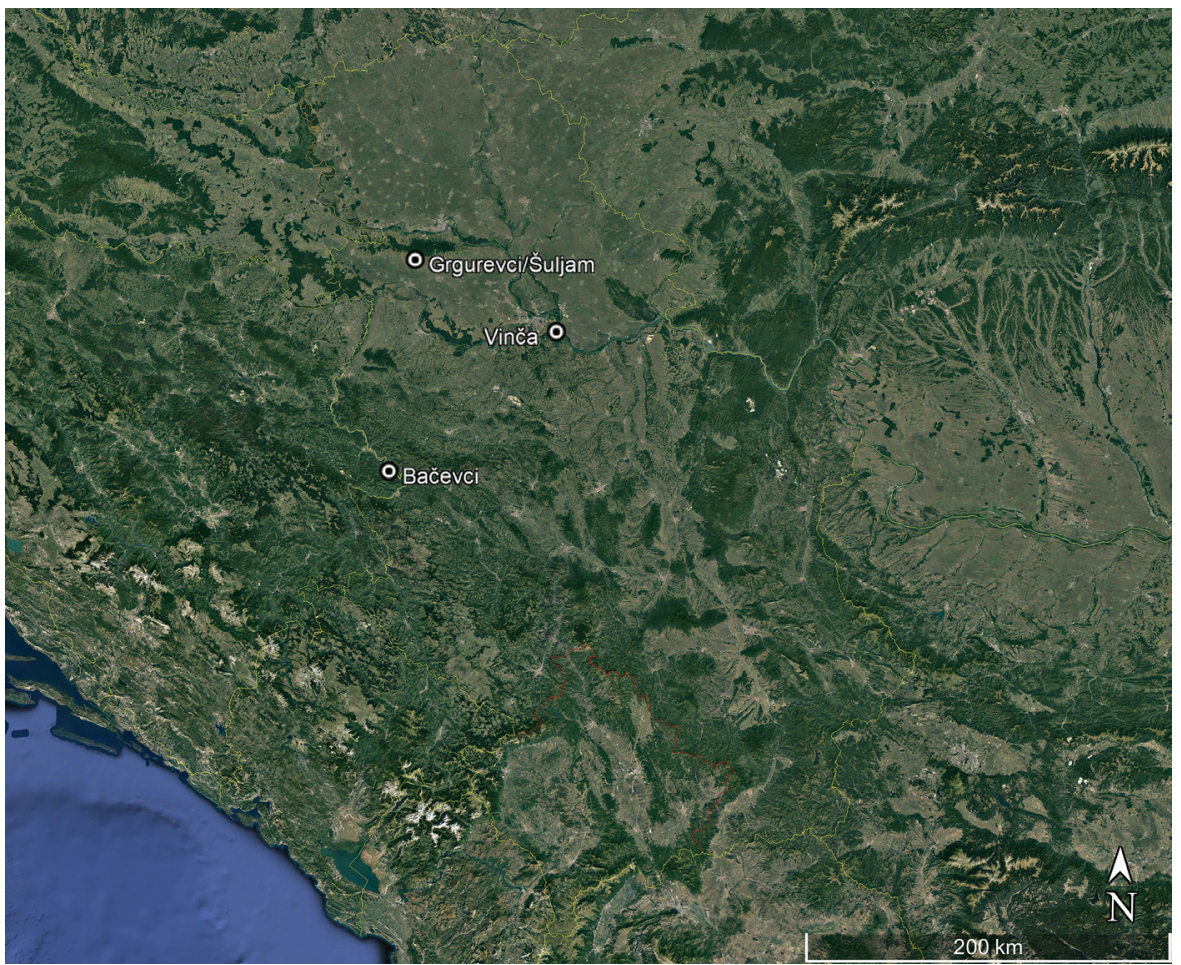

Fig. 1. Map of sites in Serbia with winged spearheads

Сл. 1. Карта налазишта копаља са крилцима у Србији

survey of a World War I battlefield. The spearhead was given to a bayonet collector, who kindly sent it to the author to examine, analyze, and publish, allowing the wood to be sampled for botanical analysis and possible radiocarbon dating. He wished to remain anonymous.

According to its owner, the spearhead was found in Bačevci, a small village in western Serbia, situated between Ljubovija and Bajina Bašta, near the confluence of the river Bačevačka Reka into the Drina. He claims that the spearhead was not taken out of the Drina or its banks, but rather found in its vicinity, although the exact finding site has never been revealed. During World War I, a trench war between Serbian and Austro-Hungarian armies raged along the Drina, including the areas near Bačevci (Игњић 1985, 324). Therefore, it is plausible that this medieval weapon was dug out from a $20^{\text {th }}$-century battlefield.

The spearhead is well preserved despite the lack of proper conservation (P1. I). Corrosion damaged the blade's surface layer and created holes in the socket.

The spearhead is $428 \mathrm{~mm}$ long, and it weighs $980 \mathrm{~g}$. A deltoid shaped blade has a rhomboid cross-section. It is $300 \mathrm{~mm}$ long, with a maximum width of 
$56 \mathrm{~mm}$ at the bottom of the blade, $259 \mathrm{~mm}$ below the tip. At this point, the blade is $16 \mathrm{~mm}$ thick. X-radiography revealed no signs of pattern welding or any other significant changes in metal consistency (Pl. I: 4-6).

The bottom of the blade gently and gradually transforms into a simple undecorated socket with a circular cross-section. The socket is $128 \mathrm{~mm}$ long; its outer diameter is $44 \mathrm{~mm}$; inner $-39 \mathrm{~mm}$. Rounded, almost oval and equally wide (17 mm each) wings sit $27 \mathrm{~mm}$ above the socket's mouth. The wings' span is 93 $\mathrm{mm}$ (one wing is $27 \mathrm{~mm}$ long, the other $30 \mathrm{~mm}$ ). Below each wing, there is one iron nail piercing the socket $21 \mathrm{~mm}$ above its mouth. The head of one of them is missing. The nails hold the remains of a wooden shaft that once carried the spearhead in place (Pl. I: 9-10).

\section{Other winged spearheads from Serbia}

The National Museum in Belgrade purchased a winged spearhead from an inhabitant of Vinča in 1955 (Марјановић-Вујовић 1984, 132-133, cat. no. 326; Нинковић 2009, 465). László Kovács published its length, keeping place, inventory number, and a simple sketch, describing it as a stray find (Kovács 1980, 102, 356, Taf. 64: 4). The sketch represents the spearhead as more robust than it actually is. The authors of two exhibition catalogues considered it an inventory item from a destroyed grave, providing a photograph (Марјановић-Вујовић 1984, 92, 133, cat. no. 326, fig. 326) and a slightly different but still very simple sketch (Јанковић и Јанковић 1990, 82, cat. no. 28.13). Veselinka Ninković supplemented the description of the spearhead with additional details, measurements, and a new drawing (Нинковић 2009, 464, T. III: 1).

The spearhead from Vinča (P1. II: 1-6) has a long, deltoid-shaped blade with a rhomboid cross-section, a narrow socket with an octagonal cross-section, and two almost identical wings with flat tops and concave bottoms. Two vertical grooves trim the end of each wing.

The spearhead is $425 \mathrm{~mm}$ long, and it weighs $587 \mathrm{~g}$. The blade with pronounced ridges and damaged edges is $305 \mathrm{~mm}$ long. It reaches its maximal width of $41 \mathrm{~mm}$ at the bottom (11 mm thick), which sharply converts into an undecorated socket. The socket is $120 \mathrm{~mm}$ long and $89 \mathrm{~mm}$ deep; its outer diameter is 31 $\mathrm{mm}$; inner $-26 \mathrm{~mm}$. The wings sit slightly above the socket's mouth. Their span is $71 \mathrm{~mm}$ (each wing is $23 \mathrm{~mm}$ long). Radiographic testing showed a uniform metal structure without inconsistencies (Pl. II, 5-6).

The spearhead from the southern slopes of Fruška Gora (found in Grgurevci, Šuljam, or their vicinity) is a well preserved, long $(560 \mathrm{~mm})$ and massive (1593 g) stray find kept in the Archaeological Museum in Zagreb (Croatia). 
The permanent exhibition of the Military Museum in Belgrade displays a replica of this weapon. ${ }^{2}$

The spearhead (Pl. III) has a blade with a lenticular cross-section with an almost uniform width that reaches its maximum in the lower part of the blade. From this point, the blade gently curves toward the undecorated socket with a polygonal cross-section (octagonal in the lower and hexagonal in the upper part). Two wings with flat tops and concave bottoms sit near the socket's mouth. Two vertical grooves trim the end of each wing, and one iron nail pierces the bottom of each wing (a nail per wing). Two small juts placed below each of the blade's edges decorate the blade-socket connection. The radiographic examination did not show traces of pattern welding. However, a circular motif of higher transparency to X-rays emerged in the lower part of the blade - an inlay of a more radiolucent metal or a faded gentle imprint (Sajdl 2018, 150, Pl. 1-4).

Archaeologists labelled a winged spearhead from a destroyed necropolis in Prilipac near Požega (Pl. II: 7-8) as Carolingian and dated it into the beginning of the $9^{\text {th }}$ century (Зотовић et al. 1978, 118; Бућић и Петровић 1985, 13, сл. 10h), or the $9^{\text {th }} / 10^{\text {th }}$ century (Мандић $1995,33,94$, Т. XX: 1). However, it probably belongs to the late Middle Ages, since it differs in shape and size from the early medieval pieces. Also, its wings are not in the same plane with the blade surface; they are perpendicular to it. The Military Museum in Belgrade keeps a similar spearhead from the $14^{\text {th }} / 15^{\text {th }}$ century found in Liplje near Ljig (Пековић 2006, 121, inv. no. 16041). Due to its probable late medieval date, the spearhead from Prilipac will not be further discussed in this paper.

\section{Remains of the wooden shaft}

As a rule of thumb, wooden spear shafts do not survive in archaeological records. Analyses of scarce fragmentary shaft remains showed that, in the early Middle Ages, they were usually crafted from elastic hardwood such as ash and, less frequently, hazel in North-western Europe (Haneca and Deforce 2020, 8), or beech, oak, and mulberry in the Carpathian Basin (Csiky 2015, 51; Husár 2008, 458-459), although softwood such as silver fir seems to be occasionally used as well (Haneca and Deforce 2020, 8; Husár 2008, 460). Several other wood taxa were used for spear shaft production, but rarely (Haneca and Deforce 2020, 8; Husár 2008, 457-461). Preserved remains of the shafts that carried winged spearheads were made of ash (Milošević 2000a, 254; Sekelj Ivančan 2004, 110) and beech (Schwarzer 2004, 363).

\footnotetext{
${ }^{2}$ According to Mirko Peković, museum advisor and curator of the Archeological Collection in the Military Museum, replicas of archaeological finds kept in various museums from the territory of former Yugoslavia were crafted in the Archeological Museum in Zagreb between 1957 and 1961 to be exhibited in the Military Museum. The idea behind this activity lies beyond the scope of this paper.
} 
The socket of the Bačevci spearhead holds crumbling and decaying pieces of a wooden shaft, which took the colour of the rust. A small fragment of wood was cut out for a biological analysis and possible radiocarbon dating. The microscopic examination of the specimen indicates that the remains are that of a hardwood, specifically a beech tree (genus Fagus L.). ${ }^{3}$

Experts disagree on the taxonomy of the genus Fagus, beginning with the number of species it includes (Denk et al. 2002, 214). According to the traditional classification, two taxa dominate Europe and Southwestern Asia - Fagus sylvatica L. and Fagus orientalis Lipsky. Fagus sylvatica L. spreads from southern Scandinavia, across Western and Central Europe up to South-eastern Europe, Sicily and Spain, while Fagus orientalis Lipsky can be found on the Balkan Peninsula, Caucasus, Anatolia, northern Iran and Crimean Peninsula (Tutin 1964, 61; Jovanović i Cvjetićanin 2005, 82). Significant taxa for Serbia, with its complex taxonomy history, is Fagus moesiaca Domin, Maly/Czeczott (Jovanović 2000, 201-211; Denk et al. 2002, 214; Jovanović i Cvjetićanin 2005, 75-77), although $F$. sylvatica and $F$. orientalis occur as well (Jovanović 2000, 213; Jovanović i Cvjetićanin 2005, 77). However, a nuclear rDNA study of Fagus in Europe and Asia Minor showed that Fagus sylvatica L. is the only species on this territory, while F. orientalis and F. moesiaca should be "treated as synonyms of Fagus sylvatica" (Denk et al. 2002, 213).

Estimates of shaft length for the spears with winged spearheads vary from 150-200 cm (Szameit 1987, 155) to 200-250 cm (Husár 2006, 48) or even 240-400 cm (DeVries and Smith 2007, 76). Using the diameter of the preserved shaft remains, Schwarzer concluded that the shafts could have been "several meters long" (Schwarzer 2004, 384), while Kurasiński estimated the length of two Polish spear shafts to cca. 180 and cca. $260 \mathrm{~cm}$ based on the size of the grave pits (Kurasiński 2005, 173). Analyzing early medieval graves with spear remains from Slovakia, Husár determined that the total spear length (including the spearhead) varied from 125-233.4 cm for infantry to 170-240/266 for cavalry (Husár 2008, 461-465), but the analysis was not limited to spears with winged spearheads. The scarcity of evidence prevents forming an estimate of the length of the spear shaft from Bačevci.

\footnotetext{
${ }^{3}$ Dragica Vilotić, PhD, professor at the Faculty of Forestry, University of Belgrade, sampled and analyzed the wood remains. Macroscopic analysis of the small crumbling rust-colored sample did not yield results. Professor Vilotić prepared temporary anatomic samples for microscopic observation by cutting the specimen into extremely thin slices using Reichert microtome. She determined biological genus of the sample from transversal, radial, and tangential cross-sections $15 \mu \mathrm{m}$ thick, observing and photographing them on a Boeco microscope.
} 


\section{Comparisons}

The author compared winged spearheads from Serbia with morphologically and technologically analogous weapons known from archaeological literature. The main characteristics used for comparisons are contours, dimensions and proportions, weight, craft technique, and decoration.

The closest analogy to the find from Bačevci is a spearhead pulled out by a scuba diver from the river Mrežnica near Duga Resa (Croatia), broadly dated between the $9^{\text {th }}$ and the $11^{\text {th }}$ century. They are similar in contour, blade and socket shape, dimensions, proportions and weight (Table 1), and both lack decoration and pattern welding. Blade edges of the Duga Resa spearhead curve slightly more and it has differently shaped wings with a wider span (Bošković 2002, 108, no. 17).

Spearhead WP5, discovered on a Byzantine shipwreck in Serçe Limanı bay (Turkey), dated into the third decade of the $11^{\text {th }}$ century (Bass 2004, 3-4), resembles the Bačevci find in contours, dimensions, and blade length/socket length ratio (Table 1). The underwater find is narrower (Table 1) and its socket crosssection is hexagonal at the top (Schwarzer 2004, 367, WP 5, Fig. 21-5, WP 5). Its weight could not be determined (Bass and van Doorninck 2004, 65).

The Bačevci spearhead and the stray find with a broken tip from Bosnia and Herzegovina (B1) share a somewhat similar contour, socket shape, wings' position, dimensions and proportions (Table 1), and they both lack decoration and pattern welding. B1 spearhead weighs less (Table 1) and has a sharper blade to socket transition, more pronounced blade ridge, and differently shaped wings (Sijarić 2014, 212, 221, T. XLV: 2).

The spearhead from Vinča shares certain features with the find from Bačevci and with spearhead B1: somewhat similar contour and blade shape, approximate dimensions (Table 1), and lack of decoration and pattern welding. The Vinča spearhead is narrower, has a socket with an octagonal cross-section, more parallel blade edges, differently positioned and shaped wings, and weighs less than the other two (Table 1). Mirsad Sijarić considered the Vinča find to be the closest analogy for the spearheads of his variant VIa dated between the second half of the $9^{\text {th }}$ and the beginning of the $11^{\text {th }}$ century, to which he included spearhead B1 (Sijarić 2014, 213, 215, T. XLV: 1-2).

The contour of the Vinča spearhead reminded László Kovács of a spearhead from Tuna (Sweden), dated into the first half of the $11^{\text {th }}$ century (Kovács 1980, 106). According to Nada Miletić, two stray finds from Bosnia and Herzegovina (B2 and B3) resemble the spearhead from Vinča by their sturdy shape, sharp blade to socket transition, blade to socket ratio, and dimensions (Miletić 


\begin{tabular}{|c|c|c|c|c|c|c|c|c|c|}
\hline & \multicolumn{9}{|c|}{ Find site, country / Налазиште, држава } \\
\hline & $\begin{array}{l}\text { Bačevci, Serbia / } \\
\text { Баячевни, Срйија }\end{array}$ & \begin{tabular}{|l|} 
Duga Resa, \\
Croatia /, \\
Mypa Peca, \\
Xpвarcka (1) \\
\end{tabular} & 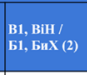 & $\begin{array}{l}\text { Vinča, Serbia/ } \\
\text { Виича, Срб̄ија }\end{array}$ & $\begin{array}{l}\text { Serse Limam } \\
\text { WP5, Turkey/ } \\
\text { Cepue Juмaнe } \\
\text { WP5, Typeka (3) } \\
\end{array}$ & $\begin{array}{l}\text { B2, BiH / } \\
\text { Б2, Бих (4) }\end{array}$ & $\begin{array}{l}\text { B3, BiH } / \\
\text { F3, } \operatorname{suX}(5)\end{array}$ & 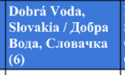 & $\begin{array}{l}\text { Fruskka Gora, } \\
\text { Serbia/ } \\
\text { Oppyika ropa, } \\
\text { Cpouja } \\
\end{array}$ \\
\hline \begin{tabular}{|l|} 
Length $(\mathrm{mm})$ ) \\
Дужина $(\mathrm{mm})$
\end{tabular} & 428 & 431 & 404* & 425 & 428 & $517^{*}$ & 495 & \begin{tabular}{|l|}
480 \\
\end{tabular} & 560 \\
\hline $\begin{array}{l}\text { Blade length }(\mathrm{mm}) / \\
\text { Дyжина болаза }(\mathrm{mm})\end{array}$ & 300 & 308 & $280^{\star}$ & 305 & 306 & $385^{*}$ & 368 & 390 & 386 \\
\hline 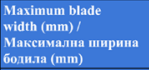 & 56 & 54.5 & 58 & 41 & 40 & 65 & 56 & 51 & 63 \\
\hline $\begin{array}{l}\text { Socket length }(\mathrm{mm}) / \\
\text { Дужина тулаз }(\mathrm{mm})\end{array}$ & 128 & 123 & 124 & 120 & 122 & 132 & 127 & 90 & 174 \\
\hline 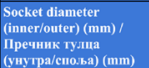 & $39 / 44$ & $43 / 44$ & 41 & $26 / 31$ & $27 / 30$ & $?$ & ? & $18 / 29$ & $32 / 38$ \\
\hline 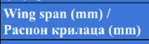 & 93 & 125 & $72^{*}$ & 71 & cса. $94^{*}$ & N/A & $\mathrm{N} / \mathrm{A}$ & $?$ & 118 \\
\hline $\begin{array}{l}\text { Blade length : } \\
\text { Blade width } / \\
\text { Дужина бодияа : } \\
\text { ширнан бодияа } \\
\end{array}$ & 5.36 & 5.65 & $>4.82$ & 7.44 & 7.65 & $>5.92$ & 6.57 & 7.65 & 6.13 \\
\hline $\begin{array}{l}\text { Blade Iength : } \\
\text { Socket length/ } \\
\text { Лужина болила : } \\
\text { Дужина тульа } \\
\end{array}$ & 2.34 & 2.5 & $>2.26$ & 2.54 & 2.51 & $>2.92$ & 2.9 & 4.33 & 2.22 \\
\hline $\begin{array}{l}\text { Weight }(\mathrm{g}) / \\
\text { Maca (g) }\end{array}$ & 980 & 900 & 793.5 & 587 & $?$ & 1333 & 1113.7 & ? & 1593 \\
\hline $\begin{array}{l}\text { Westphal's Type/ } \\
\text { Tyu upexa Becripary }\end{array}$ & "II & III & & 11/III & & III & IIII & & IIII \\
\hline
\end{tabular}

Table 1. Measurements, proportions, weight and type according to

Westphal's typology of the winged spearheads from Serbia and comparison examples (*damaged; B1, B2, B3 - unknown find site in $\mathrm{BiH}$ )

Data according to: $(1,4,5)$ Demo 2011, 72, Tablica 3, 74, Tablica 4; (2) Sijarić 2014, 221, Tabela 15, br. 27; (3) Schwarzer 2004, 389, Table 21-3; (6) Kovács 1980, 98

Табела 1. Димензије, пропорције, маса и тип према Вестфалу копаља са крилцима из Србије и поредбених примерака (*оштећено; В1, В2, В3 - непознато налазиште у БиХ)

Подаци према: (1, 4, 5) Demo 2011, 72, Tablica 3, 74, Tablica 4; (2) Sijarić 2014, 221, Tabela 15, br. 27; (3) Schwarzer 2004, 389, Table 21-3; (6) Kovács 1980, 98

1991, 204). They have a somewhat similar contour. However, they differ considerably: the finds from Bosnia are larger, more robust, weigh approximately two times more (Table 1), and have socket grooves; additionally, spearhead B2 has a socket with a circular cross-section and a blade with an engraved cross (Miletić 1991, 204, T. IV: 1-2). Veselinka Ninković found the closest analogy for the Vinča spearhead in the $9^{\text {th }}$-century find from Dobrá Voda (Slovakia) (Нинковић 2009, 465). These two spearheads bear almost no resemblance. The spearhead from Dobrá Voda has a blade with arch-shaped edges and lenticular cross-section, narrow socket with a hexagonal cross-section in the upper and nearly rectangular cross-section in the lower part, and short trapezoidal wings positioned slightly above the socket mouth. Both spearheads lack decoration and pattern welding and have an approximate blade length/blade width ratio (Table 1) (Ruttkay 1978, 27, 104, cat. no. 9; Kovács 1980, 98; Husár 2014, Tab. XVIII: 1).

The find from Vinča resembles the Serçe Limanı spearhead WP5 the most. They have very similar contours, blade shape, dimensions, and proportions 
(Table 1). Spearhead WP5 differs by its oval blade tip, socket cross-section that is hexagonal at the top and circular at the bottom, and larger wingspan (Schwarzer 2004, 367, WP 5, Fig. 21-5, WP 5).

The closest analogy for the Fruška Gora find is the $10^{\text {th }} / 11^{\text {th }}$ century spearhead from Malá Kopanja (Ukraine). Similar in contour, dimensions, proportions, and lack of socket grooves, they differ in wing shape and blade cross-section (Kovács 1980, 100, 106, Taf. 64: 1; Sajdl 2018, 150, Tables 1-2). The find from Lubon (Poland), dated into the end of $10^{\text {th }}$ and the first half of the $11^{\text {th }}$ century, and spearhead WP6 from Serçe Limanı wreck (Turkey) mirror the Fruška Gora find in contour and lack of socket grooves but differ in proportions and placement of wings (Kurasiński 2005, 169-170, Abb. 5; Schwarzer 2004, 367, 369, WP 6, Fig. 21-6, WP 6, 389, Tab. 21, 3; Sajdl 2018, 150-151, Tables 1-2). The Fruška Gora find is similar in weight, size, proportions, and the lack of socket grooves with the spearhead found in the Danube near Budapest and a stray find from the Museum of Republika Srpska, but they differ in shape (Kovács 1980, 98, 105, Taf. 61: 4; Sijarić 2014, 212-213, 221, T. XLV: 1; Sajdl 2018, 151, Tables 1-2).

\section{Typology and dating}

According to the well-known Peter Paulsen's classification, the spearheads from Serbia could probably be included in his second group of the Flügellanze mit vollendeter Form, characterized by the lack of socket grooves and 10-15 cm wingspan, dated into the period up to the year 1000 (Paulsen 1967, 257-259, 262-264). Although only the spearhead from Fruška Gora has the wingspan over $10 \mathrm{~cm}$, and the one from Bačevci has somewhat archaically shaped wings, they all lack socket grooves and pattern welding.

According to Martin Husár's typology of the spearheads from the Carpathian Basin, the spearheads from Vinča and Fruška Gora belong to his variant BAd: winged spearheads with wide, flat, straight-topped and concave-bottomed wings (Husár 2014, 33, Tab. XVIII-XXVI). The spearhead from Bačevci could be considered as a transitional form from his variant BAa with relatively massive but narrow wings (Husár 2014, 29-32, Tab. XVI) to his variant BAd.

Herbert Westphal developed a typology of winged spearheads based on their metrical, morphological, and technological characteristics by analyzing grave and stray finds from Germany (Westphal 2002, 221-266), with types II and III being relevant for this paper. The spearheads of Westphal's type II have a blade with a maximum width in its middle and arch-shaped edges; a socket with a circular or octagonal cross-section, diameter up to $30 \mathrm{~mm}$, and often decorative grooves; and reinforced wings often have vertical grooves trimming their 
ends. The type was dated into the second half of the $8^{\text {th }}$ and the first half of the $9^{\text {th }}$ century (Westphal 2002, 257). The type III spearheads dating from the end of the $8^{\text {th }}$ until the second half of the $9^{\text {th }}$ century have a blade with a mostly uniform width; a socket with a circular, octagonal, or square cross-section, diameter up to $38 \mathrm{~mm}$, and decorative grooves; they weigh around $1 \mathrm{~kg}$ (Westphal 2002, 258).

Martin Husár included the spearhead from Fruška Gora into Westphal's type II and the spearhead from Vinča into type III (Husár 2014, 35, n. 57-58). Proportions of the Fruška Gora spearhead (Table 1) approximate the proportions of the type II spearheads from Germany, Netherlands, and Austria (Westphal 2002, 294, Tab. 3.4.a, 296, Tab. 3.4.c, 298, Tab. 3.4.e.) and type III spearheads from Croatia and Bosnia and Herzegovina (Demo 2011, 72, Tablica 3). Due to its morphological features, dimensions, weight, and analogies it should be included in Westphal's type III and broadly dated from the middle of the $9^{\text {th }}$ to the end of the $10^{\text {th }}$ /beginning of the $11^{\text {th }}$ century (Sajdl 2018, 153).

The proportions of the Vinča spearhead (Table 1) are approximate to the proportions of type III spearheads from Germany and Netherlands (Westphal 2002, 294, Tab. 3.4.a, 296, Tab. 3.4.c.) and type II spearheads from Croatia and Bosnia and Herzegovina (Demo 2011, 72, Tablica 3). Although its blade shape is characteristic for type III, due to its dimensions, wing decoration, and weight it is closer to Westphal's type II. Researchers considered it a "typical Carolingian" or "Frankish" weapon, dating it into the second half of the $9^{\text {th }}$ century (МарјановићВујовић 1984, 92, 133, по. 326; Нинковић 2009, 465). Based on Westphal's typology, the spearhead from Vinča could be older, perhaps from the beginning of the $9^{\text {th }}$ century, since it shares features of both types II and III, but lacks pattern welding and socket grooves. Due to similarities with spearhead WP5 from Serçe Limanı shipwreck, a possibility of a later date should not be completely excluded.

While hoping for a possibility of radiocarbon dating, judging on the basis of morphological, metrical, and technological characteristics and analogies the spearhead from Bačevci could be included in Westphal's type III and roughly dated between the second half of the $9^{\text {th }}$ and the beginning of the $11^{\text {th }}$ century.

\section{On the origin}

As a rule of thumb, the researchers interpreted the appearance of winged spearheads in the Carpathian Basin and Balkan Peninsula as a consequence of the Frankish political activities in the southeast at the end of the $8^{\text {th }}$ and the beginning of the $9^{\text {th }}$ century: the creation of the Eastern March, Frankish-Avar wars (e.g. Kovács 1980, 97; Tomičić 1985, 227-228; Sekelj Ivančan 2004, 122), SlavicFrankish conflicts in the times of Liudewit or Ratimar (e.g. Bekić 2004, 174-176; 
Bitenc and Knific 2009, 328, cat. no. 91), the establishment of Frankish control in medieval Croatia (e.g. Милетић 1979, 149-150).

Their presence in the $9^{\text {th }}$ and $10^{\text {th }}$ century Carpathian Basin was explained through cultural influences of the empires on its western borders (Kovács 1980, 97, 106-107). Some of those, according to Nada Miletić, even reached Herzegovina later in the $9^{\text {th }}$ century (Miletić 1991, 204-206). On the other hand, younger finds from Slovenia were associated with Hungarian raids in Italy (Bitenc and Knific 2009, 328, cat. no. 91).

Some researchers believe that Frankish workshops produced the winged spearheads (e.g. Miletić 1991; Tomičić 1985, 224-226). Others proposed a possibility of local production based on Carolingian examples (Milošević 2000b, 132-133; Kovács 1980, 107; Ruttkay 1976, 300). That could be the case with the spearheads lacking pattern-welded blades and socket grooves found in Croatia and Bosnia and Herzegovina, as suggested by Ante Milošević (Milošević 2000b, 132-133). Joseph Schwarzer hypothesized that all the weapons from Serçe Limanı shipwreck were made in Bulgaria. Their wooden parts were crafted from two species of beech (Fagus sylvatica and Fagus orientalis) growing on southern Crimea and in southern and south-eastern parts of Bulgaria being one of the Schwarzer's main arguments (Schwarzer 2004, 363, 386, 396, n. 3). Complex taxonomy of the genus Fagus, as discussed above, and the results of the nuclear rDNA study impact the efforts to determine the origin of wooden shafts and, potentially, the spears themselves, including the spearhead from Bačevci. Even if we adopt the traditional taxonomy, we must acknowledge that Fagus sylvatica spreads all over the European continent, while Fagus orientalis grows on the eastern parts of the Balkan Peninsula and Crimea (Tutin 1964, 61). To the best of the authors' knowledge, winged spearheads have not been discovered in Bulgaria yet (Йотов 2004). Finally, a botanical analysis of the shaft remains testifies to the origin of the shaft alone, not necessarily of the iron parts of the spear (Sajdl 2018, 154). We could be seriously wrong by presuming otherwise. Until metallographic analyses are done, it is not possible to trace the production place of any of the winged spearheads from Serbia with any certainty.

\section{Conclusion}

All winged spearheads from Serbia were accidental finds. Archaeological context and absolute dating are completely missing, significantly limiting possible interpretations. For the Fruška Gora spearhead, even the exact place of discovery is unknown. The current state of knowledge of the history of the Fruška Gora region between the $9^{\text {th }}$ and $11^{\text {th }}$ century prevents tying this find to a histori- 
cal event or context (Sajdl 2018, 149-150, 154). If Syrmia, where Fruška Gora rises, became a border region of the Frankish Empire after the conquest of the Avar territories at the end of the $8^{\text {th }}$ and beginning of the $9^{\text {th }}$ century, as some authors believe (Калић-Мијушковић 1967, 28, 31-32; Gračanin 2011, 154, 175), Vinča, which is near Belgrade, was located fairly close to the empire's border. According to Gordana Marjanović-Vujović, the discovery of a winged spearhead in Vinča confirms this claim (Марјановић-Вујовић 1984, 89). The hypothesis of a destroyed grave was logical and natural (Марјановић-Вујовић 1984, 92, $132-133)$, bearing in mind that a large $8^{\text {th }}$ to $17^{\text {th }}$-century necropolis was excavated in Vinča on the right bank of the Danube, above the prehistoric horizons (Марјановић-Вујовић 1984, 87-91). Can the Vinča spearhead be a remnant of a Frankish-Avar battle instead? If we accept the proposed earlier dating (beginning of the $9^{\text {th }}$ century), it could be possible, especially if we take into account sporadic evidence of Avar presence to the south from the Sava and the Danube (Bugarski et al. 2013). The somewhat younger Bačevci spearhead could potentially, also with great caution, be tied to Serbian-Hungarian clashes in the Drina Valley at the time of archon Časlav (Благојевић 2005, 34-35; Живковић 2006, 69-71). To the best of the authors' knowledge, no other early medieval archaeological site exists in or near Bačevci. The question of ownership is also difficult to answer because weapons can easily change hands, whether in the course of a battle, as a gift, or as loot. With the amount of available reliable information, any deeper interpretation seems impossible and could lead to completely erroneous conclusions.

Acknowledgments: I would like to thank Slobodan Fidanovski, retired museum adviser of the National Museum in Belgrade, who granted me access to the Vinča spearhead and its museum documentation for the autopsy, and to Milica Stojanović, conservator in the same institution, who helped me with the entire X-radiography process. A special debt of gratitude I owe to Mihailo Milinković, former professor of medieval archaeology at the University of Belgrade, who induced me to examine the spearhead and made the Xradiography examination possible. Mirko Peković was very kind to check the documentation of the Military Museum in Belgrade and share his findings with me, and for that I am grateful. Any possible errors and omissions are mine.

\section{REFERENCES}

Bass, G. 2004. Introduction and Explanations, in Serçe Limani: An Eleventh-Century Shipwreck Vol. I, The Ship and Its Anchorage, Crew, and Passengers, eds. G. F. Bass, S. D. Matthews, J. R. Steffy, F. H. van Doorninck, Jr., 3-9. College Station: Texas A\&M University Press. 
Bass, G. and van Doorninck, Jr. F. H. 2004. Discovery, Excavation, and Conservation, in Serçe Limani: An Eleventh-Century Shipwreck Vol. I, The Ship and Its Anchorage, Crew, and Passengers, eds. G. F. Bass, S. D. Matthews, J. R. Steffy, F. H. van Doorninck, Jr., 49-72. College Station: Texas A\&M University Press.

Bekić, L. 2004. Novi nalaz ranosrednjovjekovnog koplja s krilcima. Vjesnik Arheološkog muzeja u Zagrebu, 3.s., XXXVI: 165-180.

Bitenc, P. and Knific, T. 2009. 91 Spearheads, in The Ljubljanica - a River and its Past, eds. P. Turk, J. Istenič, T. Knific, and T. Nabergoj, 328-329. Ljubljana: Narodni muzej Slovenije.

Благојевић, М. 2005. Подриње између српских средњовековних држава, у Дрина, ур. М. Благојевић, 29-67. Београд: Завод за уџбенике и наставна средства; Српско Сарајево: Завод за уџбенике и наставна средства.

Bošković, D. 2009. Slatkovodni nalazi u zbirci hladnog oružja Hrvatskoga povijesnog muzeja u Zagrebu, u Jurišićev zbornik: zbornik radova u znak sjećanja na Marija Jurišića, ur. L. Bekić, 98-133. Zagreb: Hrvatski restauratorski zavod.

Бућић, Ј. и Петровић, П. 1985. Римски VICVS и терме у Прилипцу. Ужички зборник 14: 5-21.

Bugarski, I., Miladinović-Radmilović, N., Popadić, I. and Marjanović M. 2013. Early Mediaeval Burial at Stubline near Obrenovac: Spatial, Anthropological and Archaeological Analyses of the Southernmost Avar Grave. Acta Archaeologica Carpathica XLVIII: 285-305. Csiky, G. 2015. Avar-Age Polearms and Edged Weapons: Classification, Typology, Chronology and Technology. Leiden and Boston: Brill.

Denk, T., Grimm, G., Stögerer, K., Langer, M. and Hemleben, V. 2002. The evolutionary history of Fagus in western Eurasia: Evidence from genes, morphology and the fossil record. Plant Systematics and Evolution 232: 213-236.

Demo, Ž. 2011. Ranosrednjovjekovno koplje s krilcima iz okolice Dugog Sela u svjetlu novih saznanja o ovoj vrsti oružja na motki. Archaeologia Adriatica IV: 61-84.

DeVries, K. and Smith, R. D. 2007. Medieval Weapons: An Illustrated History of Their Impact. Santa Barbara: ABC-Clio.

Gračanin, H. 2011. Južna Panonija u kasnoj antici i ranom srednjovjekovlju (od konca 4. do konca 11. stoljeća). Zagreb: Plejada.

Haneca, K. and Deforce, K. 2020. Wood use in early medieval weapon production. Archaeological and Anthropological Sciences 12/9: 1-16.

Husár, M. 2006. Včasnostredoveké krídelkovité kopije na území Karpatskej kotliny. Studia Historica Nitriensia 13: 47-78.

Husár, M. 2008. Niektoré aspekty včasnostredovekých kopijí a oštepov z územia Slovenska - otázky násad a odtlačkov textílií. Archaeologia Historica 33: 457-470.

Husár, M. 2014. Žrd'ovo-bodné zbrane včasného stredoveku v Karpatskej kotline 1. diel, Typológia a jej vyhodnotenie. Nitra: Univerzita Konštantína Filozofa.

Игњић, С. 1985. Бајина Башта и околина: до 1941. Кю. 1. Бајина Башта: Народна матична библиотека, Раднички универзитет „Милош Требињаце, Општинска конференција ССРН. 
Йотов, В. 2004. Въоръжението и снаряжението от българското средновековие (VII-XI век). Варна: Зограф.

Јанковић, Ђ. и Јанковић, М. 1990. Словени у југословенском Подунављу. Београд: Музеј града Београда.

Jovanović, B. 2000. Dendrologija. Beograd: Univerzitetska štampa.

Jovanović, B. i Cvijetićanin, R. 2005. Taksonomija, morfologija i rasprostranjenost mezijske bukve (Fagus moesiaca /Domin, Maly/ Czeczott.) u Srbiji, u Bukva u Srbiji: (Fagus moesiaca /Domin, Mally/ Czeczott.), ur. Lj. Stanojević, 75-82. Beograd: Udruženje šumarskih inženjera i tehničara Srbije i Šumarski fakultet Univerziteta.

Калић-Мијушковић, Ј. 1967. Београд у средњем веку. Београд: Српска књижевна задруга.

Kovács, L. 1980. Bemerkungen zur Bewertung der fränkischen Flügellanzen im Karpatenbecken. Mitteilungen des Archäologischen Instituts der Ungarischen Akademie der Wissenschaften 8-9: 97-120.

Kurasiński, T. 2005. Waffen im Zeichenkreis. Über die in den Gräbern auf den Gebieten des frühmittelalterlichen Polen vorgefundenen Flügellanzenspitzen. Sprawozdania Archeologiczne 57: 165-213.

Марјановић-Вујовић, Г. 1984. Старосрпска некропола, у Винча у праисторији и средюем веку, ур. С. Ћелић, 87-98, 131-136. Београд: Српска академија наука и уметности.

Мандић, М. 1995. Остаци материјалне и духовне културе античког периода и средњег века у ужичком крају, у Ужице - настанак и развој: културно-историјски преглед, ур. М. Мандић, 21-37. Ужице: Народни музеј.

Милетић, Н. 1979. Раносредњовековно копље из Могорјела. Зборник Народног музеја: археологија IX-X: 145-151.

Miletić, N. 1991. Ranosrednjovekovna koplja s krilima iz Bosne i Hercegovine, u Zbornik radova posvećenih akademiku Alojzu Bencu, Posebna izdanja, knj. XCV, Odeljenje društvenih nauka, knj. 27, ur. B. Čović, 201-208. Sarajevo: Akademija nauka i umjetnosti Bosne i Hercegovine.

Milošević, A. 2000a. Cetina kod Trilja, korito rijeke, u Hrvati i Karolinzi. Dio drugi. Katalog, ur. A. Milošević, 253-254. Split: Muzej hrvatskih arheoloških spomenika.

Milošević, A. 2000b. Karolinški utjecaji u kneževini Hrvatskoj u svjetlu arheoloških nalaza, u Hrvati i Karolinzi. Dio drugi. Rasprave i vrela, ur. A. Milošević, 106-139. Split: Muzej hrvatskih arheoloških spomenika.

Нинковић, В. 2009. Средњовековно оружје из збирки Народног музеја у Београду. Зборник Народног музеја XIX-1: 455-484.

Paulsen, P. 1967. Einige Flügellanzen aus Schwaben. Fundberichte aus Schwaben, N.F., 18/1: 255-264.

Пековић, М. 2006. Археолошка збирка Војног музеја у Београду. Београд: Српско археолошко друштво, Војни музеј - Београд.

Petersen, J. 1919. De Norske Vikingesverd: en typologisk-kronologisk Studie over vikingetidens vaaben. Kristiania: J. Dybwad. 
Pinter, Z. K. 1998. Piese de armament şi echipament militar de provenienţă carolingiană din Valea Mureşului. Studii şi cercetări de istorie veche şi arheologie 49/2: 135-144.

Ruttkay, A. 1976. Waffen und Reiterausrüstung des 9. bis zur ersten Hälfte des 14. Jahrhunderts in der Slowakei (II). Slovenská archeológia XXIV/2: 245-395.

Ruttkay, A. 1978. Umenie kované v zbraniach. Bratislava: Pallas.

Sajdl, A. 2018. An Early Medieval Winged Spearhead from Fruška Gora. Vjesnik Arheološkog muzeja u Zagrebu, 3.s., LI: 149-159.

Schwarzer, J. K. 2004. The Weapons, in Serçe Limani: An Eleventh-Century Shipwreck Vol. I, The Ship and Its Anchorage, Crew, and Passengers, eds. G. F. Bass, S. D. Matthews, J. R. Steffy, F. H. van Doorninck, Jr., 363-398. College Station: Texas A\&M University Press.

Sekelj Ivančan, T. 2004. Ranokarolinško koplje s krilcima iz šljunčare Jegeniš kod Koprivnice. Prilozi Instituta za Arheologiju u Zagrebu 21: 109-127.

Shetelig, H. ed. 1940. Viking Antiquities in Great Britain and Ireland. Part IV. Oslo: H. Aschehoug \& Co.

Sijarić, M. 2014. Hladno oružje iz Bosne i Hercegovine u arheologiji razvijenog i kasnog srednjeg vijeka. Sarajevo: Univerzitet u Sarajevu, Zemaljski muzej Bosne i Hercegovine. Szameit, E. 1987. Karolingerzeitliche Waffenfunde aus Österreich. Teil II: Die Saxe und Lanzenspitzen. Archaeologia Austriaca 71: 155-171.

Tomičić, Ž. 1985. Prilog istraživanju karolinškog oružja u Međimurju i varaždinskoj regiji. Starohrvatska prosvjeta, 3. s., 14: 209-230.

Tutin, T. G. 1964. Fagus L., in Flora Europaea Volume I: Lycopodiaceae to Platanaceae, eds. T. G. Tutin, V. H. Heywood, N. A. Burges, D. H. Valentine, S. M. Walters, and D. A. Webb, 61. Cambridge: Cambridge University Press.

Westphal, H. 2002. Franken oder Sachsen? Untersuchungen an frühmittelalterlichen Waffen, Studien zur Sachenforschung 14. Oldenburg: Isensee.

Ypey, J. 1982. Flügellanzen in niederländischen Sammlungen, in Vor-und Frühgeschichte des unteren Niederrheins Rudolf Stampfuss zum Gedächtnis, Quellenschriften zur Westdeutschen Vor- und Frühgeschichte 10, Hrsg. G. Krause, 241-267. Bonn: R. Habelt.

Зотовић, М., Игњић, С. и Муњић, Д. 1978. Пожега и околина, Књига 1. Пожега: Општински одбор Савеза удружења бораца народноослободилачког рата Пожеге, Градска библиотека.

Живковић, Т. 2006. Портрети српских владара: (IX-XII век). Београд: Завод за уџбенике и наставна средства. 


\section{Александар Сајдл}

Петроварадин

\section{РАНОСРЕДЊОВЕКОВНА КОПЉА СА КРИЛЦИМА ИЗ СРБИЈЕ}

Кључне речи: Срем, Дрина, Бачевии, Винча, Фрушка гора, копље са крилцима, рани средњи век

У Бачевцима, селу на обали Дрине, случајно је пронађен врх копља са крилцима са остацима дрвене мотке у тулцу. Са простора данашње Србије потичу још два слична, такође случајна, налаза. Врх копља из Винче је преко откупа стигао у Народни музеј у Београду, док се фрушкогорски примерак, коме није прецизно утврђено географско исходиште, чува у Археолошком музеју у Загребу.

Сва три налаза детаљно су описана и упоређена са сличним оружјем откривеним широм Европе. Приликом радиографских снимања установљено је да код винчанског и подрињског врха нема значајних промена у структури метала. При дну бодила фрушкогорског врха уочена је танка кружница са већом пропусношћу за рендгенске зраке. Ниједан врх није био израђен дамасцирањем. Према резултатима микроскопске анализе дрвена мотка копља из Бачеваца била је начињена од букве, чија сложена таксономија, уз недостатак металографских анализа, не допушта одређивање радионичког порекла.

Према Паулсеновој (Peter Paulsen) класификацији, налази из Србије могли би се вероватно уврстити у другу групу тзв. копаља са крилцима довршеног облика, датованој до око 1000. године. Врх копља из Винче уврштен је у Вестфалов (Herbert Westphal) тип II, док су врхови из Бачеваца и са Фрушке горе уврштени у тип III. На основу аналогија и типолошке анализе, врх из Винче датован је на почетак 9. века, али није одбачена могућност млађег датовања, док су врхови из Бачеваца и са Фрушке горе грубо датовани од друге половине 9. до краја 10. или почетка 11. столећа.

Оскудни историјски подаци и недостатак археолошког контекста онемогућавају сложенија и дубља тумачења. 

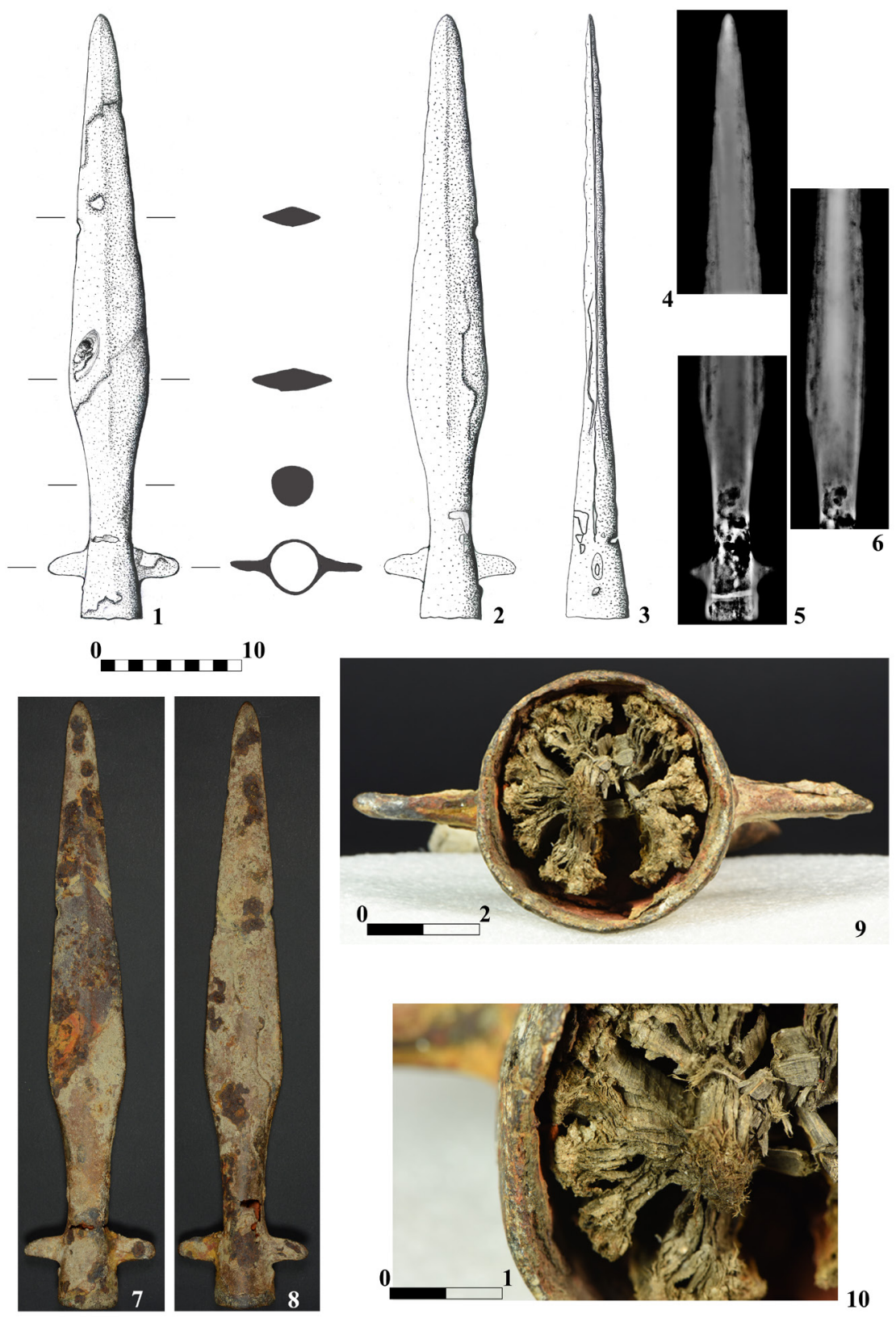

PI. I Bačevci (drawing: I. Fostikov; photo: J. Pendić; radiographs: N. Filipović, Welding Institute)

T. I Бачевци (цртеж: И. Фостиков; фото: Ј. Пендић; радиографски снимци: Н. Филиповић, Завод за заваривање) 

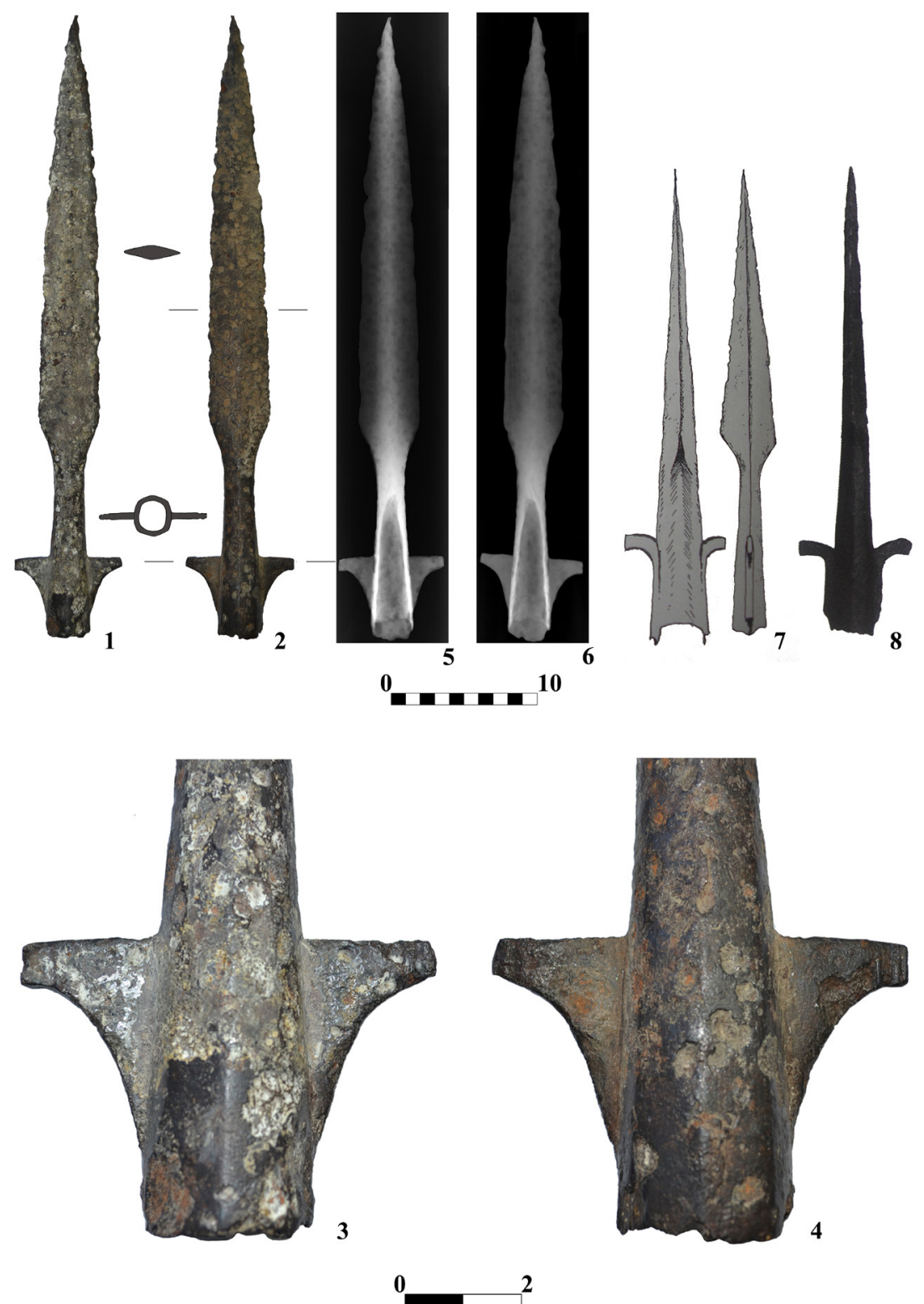

PI. II (1-6) - Vinča (cross-section drawing: A. Sajdl; photo: A. Sajdl; radiographs: V. Crnjaković, Institute for testing of materials - IMS Institute); (7) - Prilipac, Munjsko Brdo (Бућић и Петровић 1985, 13, сл. 10h); (8) - Prilipac, Munjsko Brdo (Мандић 1995, 33, 94, T. XX: 1)

T. II (1-6) - Винча (цртеж пресека: А. Сајдл; фото: А. Сајдл; радиографски снимци: В. Црњаковић, Институт ИМС); (7) - Прилипац, Муњско брдо (Бућић и Петровић 1985, 13, сл. 10h); (8) - Прилипац, Муњско брдо (Мандић 1995, 33, 94, Т. ХХ, сл. 1) 


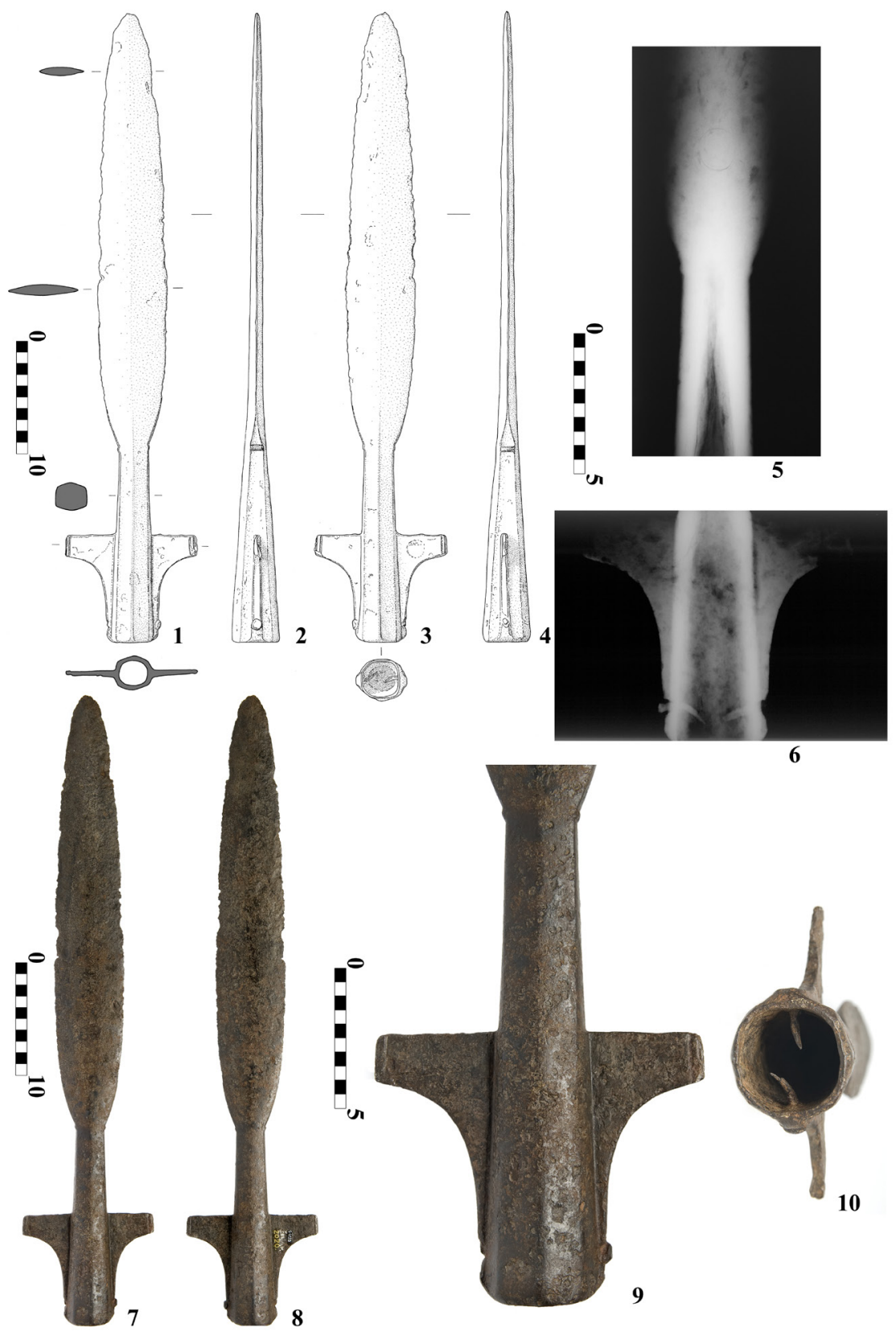

PI. III Fruška Gora (drawing: A. Dugonjić; photo: I. Krajcar; radiographs: D. Doračić)

T. III Фрушка гора (цртеж: А. Дугоњић; фото: И. Крајцар; радиографски снимци: Д. Дорачић) 